University of Chicago Law School

Chicago Unbound

Public Law and Legal Theory Working Papers

Working Papers

2016

\title{
The Uses of Religious Identity, Practice, and Dogma in 'Soft' and 'Hard' Counterterrorism
}

Aziz Huq

Follow this and additional works at: https://chicagounbound.uchicago.edu/public_law_and_legal_theory

Part of the Law Commons

Chicago Unbound includes both works in progress and final versions of articles. Please be aware that a more recent version of this article may be available on Chicago Unbound, SSRN or elsewhere.

\section{Recommended Citation}

Aziz Huq, "The Uses of Religious Identity, Practice, and Dogma in 'Soft' and 'Hard' Counterterrorism," University of Chicago Public Law \& Legal Theory Paper Series, No. 610 (2016).

This Working Paper is brought to you for free and open access by the Working Papers at Chicago Unbound. It has been accepted for inclusion in Public Law and Legal Theory Working Papers by an authorized administrator of Chicago Unbound. For more information, please contact unbound@law.uchicago.edu. 


\section{CHICAGO}

Public LaW ANd Legal Theory Working PAPer No. 609

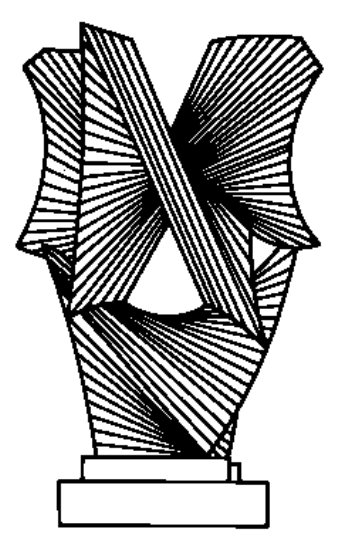

THE USES OF RELIGIOUS IDENTITY, PRACTICE, AND DOGMA IN 'SOFT' AND 'HARD' COUNTERTERRORISM

Aziz Huq

THE LAW SCHOOL

THE UNIVERSITY OF CHICAGO

November 2016 


\title{
The Uses of Religious Identity, Practice, and Dogma in 'Soft' and 'Hard' Counterterrorism
}

Aziz Z. Huq, University of Chicago Law School

Forthcoming in Security and Human Rights

(Liora Lazarus \& Benjamin Goold, eds. Hart Pub. 2017)

\begin{abstract}
This chapter maps the complex intersection between concepts of Islam and the Muslim and counterterrorism law and policy. Faith is no longer weaponized only by violent terrorist groups. States too have realized that Islam can be deployed under a security banner in a variety of ideological and practical ways. At the same time, a fractious wave of right-of-center populism has crashed over northern Europe and the United States with demands for newly restrictive rules for the citizenship and migration of Muslims. As a result, Islamic identity and practice now play three distinct roles in counterterrorism law and policy-as proxy for risk, object for reform, and object of extirpation. The result of these trends is a sharp rise in formal and informal contestation over the nature and legitimacy of Islam as a religious identity.
\end{abstract}




\section{Introduction}

What role should religious identity, practice, and dogma play in security-related policies and laws trained upon organizations such as the Islamic State (IS) and al Qaeda? Today, this question is centrally about Islamic dogma and the identity-related practices of those perceived to be Muslim. It is also as contested today as it was more than a decade and a half ago, when al Qaeda burst onto the global geopolitical stage. Today, faith is no longer weaponized by violent terrorist groups alone. States too have realized that Islam can be deployed under a security banner in a variety of ideological and practical ways. At the same time, a fractious wave of right-ofcenter populism has crashed over northern Europe and the United States with demands for newly restrictive rules for the citizenship and migration of Muslims. ${ }^{1}$ The result of these trends is continued, sharp contestation over the uses of Islam in counterterrorism and coterminous policy fields.

At one point in time, the normative and human rights implications of religion's intersection with national security turned on the narrow question of whether religious identity could lawfully be used as an effective criterion for investigation or coercive action. Now, religious identity and practice play more complex and ambiguous roles across a range of both 'hard' coercive actions and also 'soft,' more regulatory counterterrorism interventions. Islam is no longer solely a signal and proxy of risk, but also an object for reform or an object for extirpation. At security policy's periphery, pejorative conceptions of Islam exercise a gravitational pull on contiguous policy domains such as immigration, a pull amplified by partisan mobilizations and exogenous shocks such as the financial recession and the Syrian refugee crisis. As Didier Bigo perceptively framed the matter more than a decade ago, those contiguous policy domains have become thoroughly "securitized."

My aim in this chapter is to map the intersection between concepts of Islam and the Muslim and counterterrorism law and policy. This intersection is increasingly complex, and a narrow focus on religious discrimination as reflected by religious profiling is no longer apposite.. To be sure, larger strategic and partisan trends have sustained and expanded religious profiling. But they have also motivated novel mobilization of ideas about Islam and Muslims in the service of security-related policies By illustrating three distinct ways in which Islamic identity and practice now do work in counterterrorism law and policy-as proxy for risk, object for reform, and object of extirpation-I hope to clear space for new legal and normative inquiries. These underscore the value of considering dynamic, political effects from the parallel phenomena of regulation by faith and regulation of faith.

\section{Why are Muslims Still the Problem?}

In the immediate aftermath of the 2001 attacks on the eastern American seaboard, the 2004 attack on Madrid's Atocha station, and the 2005 London attacks, security policymakers in affected jurisdictions faced a situation of uncertainty rather than risk. They did not know who was a security risk. Nor did they know the magnitude of the aggregate risk. Given al Qaeda's putative

\footnotetext{
${ }^{1}$ Y 1 lmaz F, 'Right-Wing Hegemony and Immigration: How the Populist Far-Right Achieved Hegemony through the Immigration Debate in Europe' (2012) 60 Current Sociology 368. The magnitude of new restrictions on immigration varies widely, and at least until now, marginal changes to immigration policy have been small. Akkerman T,

'Immigration Policy and Electoral Competition in Western Europe A Fine-Grained Analysis of Party Positions over the Past Two Decades' (2015) 21 Party Politics 54

${ }^{2}$ Bigo D, 'Security and Immigration: Toward a Critique of the Governmentality of Unease' (2002) 27 Alternatives: Global, Local, Political 63.
} 
inspiration in Islamic doctrine, it was disappointing, although not especially surprising, that a first generation of investigative and preventive measures used Muslim identity as a predicate for investigation.

But time passed. New attacks did not proliferate after 2001. The notion that sleeper cells were strewn willy-nilly across the Ruhr or the Midwestern rustbelt seemed increasingly the stuff of lurid cinematic fantasy. As the sociologist Charles Kurzman keenly observed, increasingly the question being prompted by (non-)events was why al Qaeda's investment in visually spectacular terrorism had failed to generate recruiting dividends. ${ }^{3}$ Where, Kurzman asked, were the "missing" martyrs Osama bin Laden had hoped to inspire? To be sure, few asked that question. Nevertheless, the terrifying uncertainty of an unknown unknown receded into a merely known unknown. Terrorism was on its way to becoming just another species of risk to be calibrated and managed. As a result, the felt need for broad, prophylactic criteria of suspicion may have somewhat ebbed — at least until the IS arrived in 2014.

Nevertheless, post-2001 contestation over religion as criterion and concept in counterterrorism law and policy never quite abated in either the United States or Europe. To the contrary, categorical denunciation of Muslims as security risks have ebbed and flowed in political campaigns throughout this period. At the policy level, no legal or policy resolution was reached on whether religious identity could be used as a proxy for terrorism risk. And as this chapter demonstrates, the range of ways in which Islamic concepts and criteria were deployed in counterterrorism law and policy only expanded over time through a process of accretion and incremental policy change.

I see two larger dynamics at work behind the stubborn persistence of Islam's contested status in the counterterrorism sphere. First, violent Islamist groups have long mobilized a claim to shared religious identity, embedded in putative postcolonial heritages, as a ground of affiliation with potential recruits in Europe and America. This is reflected in the geographic location of the evolving threat. In the immediate wake of the 2001 attacks, al Qaeda was based around the Durand Line of 1893, separating Afghanistan from Pakistan and marking the farthest extent of nineteenth century British colonial power. In al Qaeda's own accounts of its turn toward the 'far enemy' of America, anticolonial tropes in Islamist garb also play a considerable role. ${ }^{4}$ Similarly, the rapid rise of IS has refocused attention onto a zone centering on the 1916 Skyes-Picot line, and extending into Syria, Iraq, and Turkey. ${ }^{5}$ The IS has celebrated its repudiation of that 1916 postcolonial dispensation, again as a means of signaling a distinctively anticolonial Islamic political identity.

To encourage the flow of recruits from Europe and elsewhere, the IS has used an aggressive social media strategy that tries to forge affinities of identity among potential supporters and recruiters. ${ }^{6}$ The idea of a religious identity, albeit one that trades on anticolonial

\footnotetext{
${ }^{3}$ Kurzman C, The Missing Martyrs: Why There Are So Few Muslim Terrorists (1 edition, Oxford University Press 2011).

${ }^{4}$ Gerges FA, 'The Far Enemy: Why Jihad Went Global' (Foreign Affairs, 28 January 2009)

$<$ https://www.foreignaffairs.com/reviews/capsule-review/2005-11-01/far-enemy-why-jihad-went-global> accessed 13

September 2016

${ }^{5}$ Cockburn P, The Rise of Islamic State: ISIS and the New Sunni Revolution (New York, Verso Books 2015).

${ }^{6}$ Weimann G, 'The Emerging Role of Social Media in the Recruitment of Foreign Fighters' in Andrea de Guttry, Francesca Capone and Christophe Paulussen (eds), Foreign Fighters under International Law and Beyond (TMC Asser Press 2016) <http://link.springer.com/chapter/10.1007/978-94-6265-099-2_6> accessed 13 September 2016; Ingram HJ, 'The Strategic Logic of Islamic State Information Operations' (2015) 69 Australian Journal of International Affairs 729; Farwell JP, 'The Media Strategy of ISIS' (2014) 56 Survival 49. In a single week in April 2015, the Islamic State week IS put out 123 different media releases—one average 18 per day. Zelin AY, 'Picture Or It Didn’t Happen: A
} 
motifs and resentments, threads through IS propaganda. Hence, a significant number of IS communications twin an agenda of doctrinal purity with the organization's claim to be a successor of the caliphate abolished by the Kemelist regime on March 3, 1924. ${ }^{7}$ It is not possible to demonstrate with precision whether, or to what extent, this claim to anticolonial religious affiliation is successful. But there is some reason to think it has struck a chord that al Qaeda's propaganda operation never touched. One study estimates that roughly 30,000 foreign fighters entered Syria and Iraq to fight alongside IS between 2011 and $2015 .^{8}$ The extent and sophistication of IS propaganda has, at a minimum, engendered a perception that a new ideological front has opened in counterterrorism. In this new context, Islam operates as a shared basis of identity, albeit one grounded in historical anticolonial struggles, and one that seems to have some appeal for disenfranchised minority communities in former colonial states.

A second dynamic emerges over a longer time-frame as counterterrorism policy adapted to the strategic deployment of a historicized Islam as a basis for mobilization and recruitment. The September 2001 attacks precipitated dramatic institutional and legal shifts in the counterterrorism policy and practice of the United States, European states, the European Union, and the United Nations. ${ }^{9}$ In this first post-2001 iteration, counterterrorism policy was rarely framed explicitly in terms of Islamic concepts and categories. But faith still operated sub rosa as a basis for investigation and coercion, albeit often not in explicit terms. A central legal and normative question raised by new legal authorities of detention, surveillance, and restraint was therefore whether such powers were appropriately deployed predominantly against individuals perceived to be Muslim. ${ }^{10}$

A decade later, the incidence of Islamic concepts and the use of Islam as a criterion has proliferated far beyond questions of profiling. To a large extent, this has been driven by concerns about the inefficacy of 'hard' state power against domestic recruitment by IS and al Qaeda. Starting with the Netherlands and the United Kingdom, a number of European states, the European Union, and the United States have adopted alternative, 'soft' policies of 'counterradicalization. ${ }^{11}$

Counter-radicalization policies are united by the aim of influencing the doxa and practice of Muslims. But they still take many forms, including selective support for certain religious groups; state regulation of religious practice and imams; and the suppression of sects perceived as

Snapshot of the Islamic State's Official Media Output' (2015) 9 Perspectives on Terrorism

$<$ http://www.terrorismanalysts.com/pt/index.php/pot/article/view/445> accessed 13 September 2016

${ }^{7}$ Zelin 2016; Kennedy H, The Caliphate (London, Pelican 2016).

${ }^{8}$ Bakker E and Singleton M, 'Foreign Fighters in the Syria and Iraq Conflict: Statistics and Characteristics of a Rapidly Growing Phenomenon' in Andrea de Guttry, Francesca Capone and Christophe Paulussen (eds), Foreign Fighters under International Law and Beyond (TMC Asser Press 2016) <http://link.springer.com/chapter/10.1007/978-94-6265099-2_2> accessed 13 September 2016. For a more contextual study of the flow of fighters from a single Danish city (Aarhus), see Lindekilde L, Bertelsen P and Stohl M, 'Who Goes, Why, and With What Effects: The Problem of Foreign Fighters from Europe' (2016) 27 Small Wars \& Insurgencies 858

${ }^{9}$ Many other countries also altered their security-related legal regimes after 2001, partially in response to United Nations Security Council resolutions seeking changes. Scheppele KL, 'Other People's Patriot Acts: Europe's Response to September 11' (2004) 50 Loyola Law Review 89.

${ }^{10}$ Harcourt B, Muslim Profiles Post 9/11: 'Is Racial Profiling an Effective Counter-terrorism Measure and Does it Violate the Right to be Free from Discrimination,' in Goold BJ and Lazarus L (eds), Security and Human Rights (London, Bloomsbury Publishing 2007).

${ }^{11}$ Bakker E, 'EU Counter-Radicalization Policies: A Comprehensive and Consistent Approach?' (2015) 30 Intelligence and National Security 281 (European Union); Heath-Kelly C, 'Counter-Terrorism and the Counterfactual: Producing the "Radicalisation" Discourse and the UK PREVENT Strategy' (2013) 15 British Journal of Politics and International Relations 394 (United Kingdom); Huq AZ, 'The Social Production of National Security' (2013) 98 Cornell Law Review 637 (United States and United Kingdom). 
affiliated with terrorism groups. This heterogeneity reflects persisting doubt as to whether there is a stable phenomenon of 'radicalization,' ${ }^{12}$ as well as disagreements about how ideological persuasion is best countered.

Different countries have taken very different approaches to the mix of 'hard' and 'soft' counterterrorism tools. At one extreme, the Netherlands and the United Kingdom were early adopters of counter-radicalization. Both subsequently experimented with a range of milder policies. These include theological interventions, counter-messaging, and interventions by teachers, social workers, and child protective services. ${ }^{13}$ In contrast, France did not have a national counter-radicalization policy until April 2014. Instead, a network of French counterterrorism institutions, spearheaded by powerful investigating judges working in close alliance with intelligence agencies, wielded hard power to generate security without much regard for a need to recognize and negotiate with divergent religious cultures. French notions of secularism (or laïcité) also preclude overt recognition of racial and religious heterogeneity, undermining the feasibility of many soft measures. ${ }^{14}$ Indeed, France's 2014 soft counterradicalization plan remains comparatively thin: It includes an experimental program for reintegration, a national center, a phone line, and a website. ${ }^{15}$

Domestic political dynamics have also motivated the inclusion of notions of Islam in counterterrorism policy. In many European countries, right-of-center populist politicians, such as the Dansk Folkeparti, the Bündnis Zukunft Österreich (Alliance for the Future of Austria), and the Dutch Party for Freedom have coalesced around restrictive immigration measures, aimed at stanching Muslim migration partly in the name of ensuring security. ${ }^{16}$ Opposition to immigration is central to these parties' appeal. ${ }^{17}$ In turn, concerns about terrorism motivate anti-immigrant sentiment. ${ }^{18}$ The result is a "securitization" of immigration policy that both reflects and reinforces the political power of the populist right. The end-point of this dynamic is illustrated by the German writer Hans Monath's 2010 pronouncement that "Islam is not part of Europe."19

\section{The Varied and Sundry Uses of Islam}

The forces described above have worked powerful changes in the ways security policy deploys concepts of Islam and the Muslim. I draw on both European and American illustrations to

\footnotetext{
${ }^{12}$ For criticisms of the term 'radicalization,' see Neumann PR, 'The Trouble with Radicalization' (2013) 89 International Affairs 873; Huq AZ, 'Modeling Terrorist Radicalization' (2010) 2 Duke Forum for Law and Social Change 39.

${ }^{13}$ Lindekilde L, 'Value for Money? Problems of Impact Assessment of Counter-Radicalisation Policies on End Target Groups: The Case of Denmark' (2012) 18 European Journal on Criminal Policy and Research 385; Coppock V and McGovern M, "Dangerous Minds"? Deconstructing Counter-Terrorism Discourse, Radicalisation and the "Psychological Vulnerability" of Muslim Children and Young People in Britain' (2014) 28 Children \& Society 242.

${ }^{14}$ Hellmuth D, 'Countering Jihadi Terrorists and Radicals the French Way' (2015) 38 Studies in Conflict and Terrorism 979; Foley F, 'Reforming Counterterrorism: Institutions and Organizational Routines in Britain and France' (2009) 18 Security Studies 435; Gregory S, 'France and the War on Terrorism' (2003) 15 Terrorism and Political Violence 124.

${ }^{15}$ Hellmuth (2015), 988.

${ }^{16}$ Hafez F, 'Shifting Borders: Islamophobia as Common Ground for Building Pan-European Right-Wing Unity' (2014) 48 Patterns of Prejudice 479, 485.

${ }^{17}$ Ivarsflaten E, 'What Unites Right-Wing Populists in Western Europe? Re-Examining Grievance Mobilization Models in Seven Successful Cases' (2008) 41 Comparative Political Studies 3; see also Rydgren J, 'Immigration Skeptics, Xenophobes or Racists? Radical Right-Wing Voting in Six West European Countries’ (2008) 47 European Journal of Political Research 737.

${ }^{18}$ Zucchino D, 'I've Become a Racist: Migrant Wave Unleashes Danish Tensions Over Identity' New York Times (5 September 2016).

${ }^{19}$ Quoted in Alexander JC, 'Struggling over the Mode of Incorporation: Backlash against Multiculturalism in Europe' (2013) 36 Ethnic and Racial Studies 531, 544.
} 
show how religious concepts and criteria can be put to work for security-related ends. The observed diversity of uses can be broken into three rough categories: Islam as a signal and proxy for risk, Islam as an object of reform, and Islam as an object of extirpation.

\section{Islam as Signal and Proxy for Risk}

Today, outward and visible signifiers of Islamic religiosity - skin pigmentation; use of Arabic or a language perceived as Middle Eastern or South Asian; beards for men; and veils for women-still serve as triggers for suspicion and official intervention in a range of contexts. These signifiers, of course, are imperfect proxies of Muslim identity. In the United States, for example, a majority of Arab-Americans are Christian. Skin pigmentation and beard length are necessary imperfect proxies for any faith. More generally, it is a serious mistake to think that all those raised in Muslim households maintain the same religious beliefs, or even any religious beliefs at all, into adulthood. Profiling measures that employ a singular and invariant definition of the Muslim, one that rather parallels the account of the Muslim in doctrinaire Islamic texts' treatment of apostasy. ${ }^{20}$

The use of a religious proxy for security risk today, though, appears to result from the dispersed actions of street-level agents or the general public. ${ }^{21}$ The counterterrorism investigations of the New York Police Department (NYPD) illustrate this trend. From 2002 onward, the NYPD's Intelligence Division and its Demographics Unit used Islamic identity as a criterion for long-term electronic and physical surveillance. Confidential informants and undercover agents targeted mosques, Muslim student associations, and social hubs in Muslimmajority neighborhoods in New York City, New Jersey, Pennsylvania, and Connecticut. ${ }^{22}$ Undercover officers targeted Muslim university students, trying to extract comments that could be used as a basis for broad conspiracy charges. ${ }^{23}$ Despite two legal challenges to these practices, and a settlement in which the NYPD purported to repudiate religious criteria, ${ }^{24}$ the Intelligence Division of the NYPD remains focused on Muslims. An August 2016 audit of that Division's activities found that "more than $95 \%$ of all files reviewed" concerned Muslim suspects. ${ }^{25}$

In the United Kingdom, Sections 44(1) and (2) and 45 of the Terrorism Act (2000) allow police to designate large geographic areas "for the purpose of searching for articles of a kind which could be used in connection with terrorism." These provisions derogated from the 1995 Police and Criminal Evidence Act by permitting street stops and searches in the absence of "due suspicion." ${ }^{, 26}$ In absolute numbers, Section 44 stops were employed more frequently against nonminorities. Ethnic minorities, however, experienced higher rates of stops, and government ministers warned that such stops would be "inevitably ... disproportionately experienced" by

\footnotetext{
${ }^{20}$ Cook D, 'Apostasy from Islam: A Historical Perspective' (2006) 31 Jerusalem Studies in Arabic and Islam 248.

${ }^{21}$ On the difficulty of regulating street-level bureaucrats, see Hupe P and Hill M, 'Street-Level Bureaucracy and Public Accountability' (2007) 85 Public Administration 279

${ }^{22}$ Apuzzo M and Goldman A, Enemies Within: Inside the NYPD's Secret Spying Unit and Bin Laden's Final Plot Against America (Touchstone 2013); Hassan v. City of New York, 804 F.3d 277 (3d Cir. 2015). Disclosure: I am counsel for the Hassan plaintiffs.

${ }^{23}$ Theoharis J, “'I Feel Like a Despised Insect”: Coming of Age Under Surveillance in New York' (The Intercept) $<$ https://theintercept.com/2016/02/18/coming-of-age-under-surveillance-in-new-york/> accessed 14 September 2016

${ }^{24}$ Apuzzo M and Baker A, 'New York to Appoint Civilian to Monitor Police's Counterterrorism Activity' The New York Times (7 January 2016) <http://www.nytimes.com/2016/01/08/nyregion/new-york-to-appoint-monitor-to-reviewpolices-counterterrorism-activity.html> accessed 14 September 2016.

${ }^{25}$ Office of the Inspector General-NYPD, 'An Investigation of NYPD's Compliance with Rules Governing Investigations of Political Activity’ (23 August 2016) < http://www1.nyc.gov/site/oignypd/reports/reports.page> accessed 22 September 2016.

${ }^{26}$ Hallsworth S, 'Racial Targeting and Social Control: Looking behind the Police' (2006) 14 Critical Criminology 293, 296.
} 
British Muslims. ${ }^{27}$ Ethnographic studies of British Pakistanis have found broad resentment of counterterrorism powers with particular umbrage directed at Section $44 .^{28}$

In France, the deployment of emergency powers has been characterized by a similar distributional pattern. These powers include warrantless home search and 'assigned residence' orders (barring a person from leaving a jurisdiction and requiring reports several times daily to a police station). After terrorist attacks in Paris on November 13, 2015, French President François Hollande declared a three-month state of emergency. As of late 2016, the state of emergency has been renewed three times. A February 2016 report by Amnesty International identified 3,242 searches between November and January and more than 350 assigned residence orders. Almost all targeted French Muslims, even absent any official religion criterion. Less than one percent of emergency action resulted in criminal investigation. ${ }^{29}$ The Amnesty report describes a pervasive pattern of violent and humiliating treatment during searches. ${ }^{30}$ It found that in many cases assigned residence orders appeared to be based on anonymous tips received though the counterradicalization hotline. Relatedly, the official justifications shared with those subject to assigned residence orders were "usually quite general," leaving subjects of investigation no way to challenge their veracity. ${ }^{31}$ Those searched noted that visible Islamic religiosity seemed to explain why they, and not neighbors, were subject to emergency powers.

These examples suggest that profiling can persist on the ground, even absent an official policy, if there is a "widespread tendency to associate Islamic behavior and Muslims generally with terrorism." ${ }^{\prime 32}$ Disparate results emerge because widely shared negative beliefs about Muslims translate into higher rates of suspicion of that class. This background dynamic, moreover, is likely to be exacerbated by political mobilizations to remove signs of Islamic religiosity from public life. In Switzerland, for example, a 2009 referendum banned the construction of minarets. ${ }^{33}$ In France, Belgium, and some Spanish and Italian towns, there are now bans on religious facial covering in public. ${ }^{34}$ Legal prohibitions on legible public manifestations of Islamic identity may have the effect of suppressing expressions of religiosity ${ }^{35}$ while also reinforcing the belief that nonconforming religious displays are repudiations of generally held social norms. As former French president Nicholas Sarkozy said of the Muslim veil, such manifestations are taken as "rejection of our values." ${ }^{36}$ Hence, when religious identity is expressed in public, it will be more unusual and more likely to elicit hostile attention.

\footnotetext{
${ }^{27}$ Pantazis C and Pemberton S, 'From the "Old" to the "New" Suspect Community Examining the Impacts of Recent UK Counter-Terrorist Legislation' (2009) 49 British Journal of Criminology 646, 656-58; Hallsworth (2004), 297-98.

${ }^{28}$ Mythen G, Walklate S and Khan F, “'I'm a Muslim, but I'm Not a Terrorist”: Victimization, Risky Identities and the Performance of Safety' (2009) 49 British Journal of Criminology 736

${ }^{29}$ Rubin AJ, 'Muslims in France Say Emergency Powers Go Too Far' The New York Times (17 February 2016)

$<$ http://www.nytimes.com/2016/02/18/world/europe/frances-emergency-powers-spur-charges-of-overreach-frommuslims.html> accessed 14 September 2016

${ }^{30}$ Amnesty International, 'Upturned Lives: The Disproportionate Impact of France's State of Emergency' (4 February

2016) < https:/www.amnesty.org/en/documents/eur21/3364/2016/en/ accessed 14 September 2016.

${ }^{31}$ Amnesty International (2016) 20-21.

${ }^{32}$ Vertigans S, 'British Muslims and the UK Government's "war on Terror" within: Evidence of a Clash of

Civilizations or Emergent de-Civilizing Processes?' (2010) 61 British Journal of Sociology 26, 33.

${ }^{33}$ Göle N, 'The Public Visibility of Islam and European Politics of Resentment: The Minarets-Mosques Debate' (2011) 37 Philosophy \& Social Criticism 383, 385-86.

34 'The Islamic Veil across Europe' BBC News (1 July 2014)<http://www.bbc.com/news/world-europe-13038095> accessed 14 September 2016.

${ }^{35}$ But in some cases, stigmatized symbols are adopted precisely because of the negative reaction they invoke. Göle N, 'The Voluntary Adoption of Islamic Stigma Symbols' (2003) 70 Social Research 809.

${ }^{36}$ Edmunds J, 'The "new” Barbarians: Governmentality, Securitization and Islam in Western Europe' (2011) 6 Contemporary Islam 67.
} 


\section{Islam as an Object for Reform}

Islam has become an object of security-related regulation in the state's hands as well as a criterion for surveillance and coercion. This occurs most markedly in counter-radicalization programs. Religious identity and practice shifts in the counter-radicalization context from a trigger of state coercion to a mutable object of state regulation. A quintessential exercise in 'governmentality,' counter-radicalization treats Islam as a malleable object of state regulation, and involves the "cultivation of [individual] subjectivity in specific forms." ${ }^{, 37}$ Its aim is not to use Islam as a proxy for risk, but to transform Islam. Given this new direction, it raises quite new and distinct concerns in respect to the scope of religious freedom and practice.

The British 'Prevent' program provides a vivid example. This national program avowedly "challeng[es] the ideologies that extremists believe can justify the use of violence, primarily by helping Muslims who wish to dispute these ideas to do so." ${ }^{38}$ A "key measure" of its success, explained the British government, would be "demonstrable changes in attitudes among Muslims." 39 It has pursued that change through religious 'roadshows,' forums, and advisory councils, a 'radicalization' toolkit for secondary education professionals, and a referral program for early interventions named "Channel." ${ }^{40}$ Prevent also contains some mandates. Secondaryschool teachers, for example, are required to report students' "radical" behaviour. ${ }^{41}$ In a single year (2008-9), £140 million was expended on Prevent with the explicit aim of altering the substantive content of Islamic beliefs. ${ }^{42}$

But Prevent has met considerable resistance from Muslim communities, service providers, and commentators. Teachers, for example, have voted to disobey the "radical" reporting requirement, while many community organizations have protested or exited governmental programs. ${ }^{43}$ Prevent has also been dogged by criticisms that it was meant, in fact, to work as a covert surveillance program. ${ }^{44}$ Such hostility highlights a subtle paradox in the program's logic. On the one hand, Prevent's avowed ambition is reformist. It is a substitute in that regard for "hard' measures. On the other hand, Prevent treats "Muslims as a security risk" and as a minority that is "poorly integrated into British society." ${ }^{45}$ In this stipulating Muslims as a categorically problematic minority, Prevent's negative expressive effect likely works at crosspurposes with its avowed reformist ambition.

Another unintended consequence of Prevent has been a securitization of welfare and social services. Funding for the Prevent program persisted though the 2008-09 financial crisis, a period in which direct welfare expenditures were plummeting. As a result, funding-starved social service providers retooled their proposals to fit a counterterrorism agenda: Welfare policy, and

\footnotetext{
${ }^{37}$ Garland D, “'Governmentality” and the Problem of Crime: Foucault, Criminology, Sociology' (1997) 1 Theoretical Criminology 173, 175.

${ }^{38}$ Quoted in Alam Y and Husband C, 'Islamophobia, Community Cohesion and Counter-Terrorism Policies in Britain' (2013) 47 Patterns of Prejudice 235, 247.

${ }^{39}$ O'Toole T and others, 'Governing through Prevent? Regulation and Contested Practice in State-Muslim Engagement' (2016) 50 Sociology 160, 162.

${ }^{40}$ Huq (2013) 654-55; Briggs R, 'Community Engagement for Counterterrorism: Lessons from the United Kingdom' (2010) 86 International Affairs 971, 971-72.

${ }^{41}$ Gayle D, 'Prevent Strategy "Could End up Promoting Extremism”" The Guardian (21 April 2016)

$<$ http://www.theguardian.com/politics/2016/apr/21/government-prevent-strategy-promoting-extremism-maina-kiai> accessed 15 September 2016

42 Briggs (2010) 971.

${ }^{43}$ O'Toole and others (2016) 172-74; Gayle (2016).

${ }^{44}$ O'Toole and others (2016) 4; Huq (2013), 655-56.

${ }^{45} \mathrm{O}$ 'Toole and others (2016) 165.
} 
the maintenance of a social safety net, became increasingly entangled with, and evaluated as, security policy. ${ }^{46}$ Paradoxically, even as the deployment of Section 44 stop-and-search powers imposed a new tax on manifest indicia of Muslim identity, the Prevent program made the same identity status a quasi-prerequisite to the availability of positive, often monetary benefits from the state.

One way to resolve these paradoxes is to use solely only rather than carrots. This has been the French way. Between 2001 and 2012, French authorities deported 166 people, including 31 imams, as "Islamists." ${ }^{47}$ Selective deportations of this sort not only influence specific mosques, but also alter the overall tenor of preaching in French mosques via their deterrent and expressive effects.

\section{Islam as an Object of Extirpation}

There is a third way in which Islam as a religion - a complex of beliefs, practices, dispositions, and religious tests - has increasingly come to be an object of regulation. This third category differs from Prevent and other reformist measures because of its ends. The state's agenda here is thoroughly negative. Explicitly or not, Islam is construed as a problem to be eliminated as inconsistent with national or transcendental 'liberal' values. The ideological gist of such policies is crisply conveyed by Slovakian Prime Minister Robert Fico's claim that "Islam has no place in Slovakia" and Hungarian Prime Minister Viktor Orbán's assertion that "Islam was never part of Europe." ${ }^{48}$ No full-scale realization of such sentiments has yet been observed (although the possibility cannot be ruled out). Nevertheless, the categorical negative force of such sentiments is echoed in both retail and wholesale security-related policies.

At a retail level, a number of security policies can have the practical effect of extinguishing religious communal life. Since November 2015, for example, French authorities have used emergency powers to shut down several mosques and Muslim community associations. ${ }^{49}$ These efforts are not without precedent. In 2005, 22 regional units comprising representatives from police, tax, prefectures, and other regulatory offices were created to fight "radical Islam." These units closed mosques, Halal butchers, and small retail establishments. ${ }^{50}$ In the United States at roughly the same time, several nationwide Islamic charities had assets frozen and officers prosecuted. ${ }^{51}$ Asset-freezing orders, criminal investigations, and prosecutions (even when unsuccessful) effectively dismantled much of the nationwide civil society that American Muslims had constructed until then.

More subtly, these policies can be understood as evidence of a belief that Muslims as a group are not, or cannot become, full citizens. Consider in this regard the revocation of citizenship measures either proposed or used in Europe. In France, President Hollande proposed a

\footnotetext{
${ }^{46}$ Thomas P, Responding to the Threat of Violent Extremism: Failing to Prevent (A\&C Black 2012)

${ }^{47}$ Ragazzi F, 'Toward "Policed Multiculturalism”? Counter-radicalization in France, the Netherlands and the United Kingdom' Centre d'Études et de Recherches Internationales (December 2014) < http://www.sciencespo.fr/ceri/sites/sciencespo.fr.ceri/files/Etude_206_anglais.pdf $>$ Few imams in France are indigenous, but rather migrate as adults to take up these positions from North Africa.

48 'Islam Is Europe's “new Fascism," and Other Things European Politicians Say about Muslims' (Washington Post) $<$ https://www.washingtonpost.com/news/worldviews/wp/2016/06/07/ten-things-outspoken-european-politicians-aresaying-about-islam/> accessed 15 September 2016.

49 Amnesty International (2016) 24. In one case (Lagny-sur-Marne), police publically announced the seizure of inculpatory evidence, but Amnesty International found that police reports of the same raids recorded that no such evidence was found.

${ }^{50}$ Ragazzi (2014) 28.

${ }^{51}$ Al-Marayati L, 'American Muslim Charities: Easy Targets in the War on Terror' (2004) 25 Pace Law Review 321.
} 
statutory mechanism for déchéance de nationalité (citizenship stripping) in December 2015 targeting dual nationals alone. The French Senate rejected the measure, but Hollande's proposal was widely understood as targeted at French Muslims alone, and to have implied their second-tier status as citizens whose loyalty is presumptively in question. ${ }^{52}$

At a more macro level, the extirpation of Islam is advanced though immigration and citizenship policies. In the United States, several Republican presidential candidates have called for categorical bars on Muslim immigration. In Europe, populist parties call for bans of a similar character. Some European nations have substantially reduced the permitted flow of lawful migrants under political pressure. One means for both slowing migrant flows, and also altering the composition of migrant flows, is the use of citizenship tests that screen based on culture or familiarity with local customs. These have been used in several European countries, including Austria, Germany, and the Netherlands with the more-or-less explicit aim of ending Muslim immigration.

The connection between security and migration is commonly rendered explicit on the face of such tests. In 2006, Heribert Rech, the interior minister of Baden-Württemberg, proposed thirty additional questions to be used on the citizenship test administered in that region. Questions expressly focused on terrorism in addition to a focus on cultural norms. So obvious was its bottom-line intent that Baden-Württemberg's test was quickly dubbed "the Muslim test." Netherlands, the content of the recently revised citizenship test focused on values of sexual freedom, gender equality, freedom of speech and individuality-assumed to be inconsistent with Islam. ${ }^{54}$ The effect of such tests falls disproportionately on citizens invoking a right to family reunification, as opposed to high-skills migrants. ${ }^{55}$ In Denmark, the citizenship test eschews such raw generalizations. Yet, the Danish test has been recently reformed to make it almost impossible to overcome even for native Danes. This led to $68.8 \%$ failure rates for new migrants. ${ }^{56}$ Introduced at a moment at which migration flows were starting to be dominated by Muslims, the timing of this change seems to reflect a deeper belief: that it is current migrants that are the problem.

Islam and the Muslim, then, are concepts with plural usages in the policy space of national security. Their use as criteria of suspicion is only part of the picture. In addition, Islam operates as a subject to be regulated and object of governmentality. The state can also aim at more categorical exclusions and prohibitions of Islam. The gap between liberal aspirations to equality and extensive personal liberty, and thoroughly illiberal forms of racial and religious discrimination, in short, is neither wide nor hard to navigate.

\section{The (New) Critique of Counterterrorism Policy's Uses of Islam}

\footnotetext{
52 Joppke C, 'Terror and the Loss of Citizenship' (2016) 20 Citizenship Studies 728, 745.

${ }^{53}$ Dempsey J, 'Civic Test in Germany Draws Fire' The New York Times (14 February 2006)

$<$ http://www.nytimes.com/2006/02/14/world/europe/civic-test-in-germany-draws-fire.html> accessed 15 September 2016. Joppke states that the test was initially applied only the Muslim applicants, although contemporaneous reporting does not reflect that. Joppke C, 'Through the European Looking Glass: Citizenship Tests in the USA, Australia, and Canada' (2013) 17 Citizenship Studies 1, 10.

${ }^{54}$ Leeuw M de and Wichelen S van, 'Civilizing Migrants: Integration, Culture and Citizenship' (2012) 15 European Journal of Cultural Studies 195.

${ }^{55}$ For a discussion of the Dutch immigration test's effects in this regard, see Goodman SW, 'Controlling Immigration through Language and Country Knowledge Requirements' (2011) 34 West European Politics 235.

${ }^{56}$ Bilefsky D, 'Denmark's Tougher Citizenship Test Stumps Even Its Natives' The New York Times (7 July 2016)

<http://www.nytimes.com/2016/07/08/world/europe/denmark-citizenship-test.html> accessed 15 September 2016.
} 
Concepts of Islam and the Muslim are exploited in many different ways across the regulatory apparatus of counterterrorism and related policies. The heterogeneity of Islam's uses suggests a need both to rethink old critiques and to develop new forms of criticism.

\section{The Limits of the Old Critiques}

In the international human rights context, as well as within many domestic law frames, a central question is the rationality of official distinctions drawn in religious terms. The focus in international human rights law is commonly on "the existence of an objective and reasonable justification for ... differential treatment" and the "existence of a reasonable relationship of proportionality between the difference in treatment and the legitimate aim sought to be realized. ${ }^{, 57}$

An assessment of the rationality of discriminatory criteria remains necessary to a comprehensive normative critique of counterterrorism policy.. But it is no longer sufficient. Consider as an example Bernard Harcourt's powerful argument against religious profiling. Harcourt pointed out that the value of faith as a signal of risk depended on the relative responses to such policing by both profiled and nonprofiled classes. Harcourt pointed out (with more sophistication and clarity than I can muster here) that if the profiled group reduces its activity, while the non-profiled group ramps it up, the profile no longer works. ${ }^{58}$ Although powerful, Harcourt's critique does not necessarily illuminate contemporary profiling. The deployments of "Muslim" or "Islamic" as criteria for state coercion today no longer follow from a rational, centralized determination that such criteria are needful. Instead, they emerge as an emergent quality of the individual preferences and beliefs of dispersed, unconnected officials (or members of the public.) Those dispersed 'street level' actors are not making a cost-benefit judgment about the epistemic value of religious traits. Rather, they are acting on intuition, half-formed belief, and spontaneous emotional coloration. Absent a centralized state making rational decisions, arguments for critique and reform should not focus on the internal logic of profiling. Rather, they must speak directly to the stereotypes and fears, .

\footnotetext{
${ }^{57}$ Moeckli D, Human Rights and Non-Discrimination in the 'War on Terror' 76-79 (Oxford, Oxford University Press 2008).

${ }^{58}$ Harcourt (2007) 88. In my view, the assumption that Harcourt queries (the relative responsiveness of Muslims' and nonMuslims' behaviours to state scrutiny) is not critical to the debate on profiling. The more important question is whether behaviour is at all responsive to profiling. The question of relative elasticities in the behavior of profiled and non-profiled groups, which is Harcourt's focus, arises from the so-called KPT model of racial profiling. Knowles J, Persico N and Todd P, 'Racial Bias in Motor Vehicle Searches: Theory and Evidence' (2001) 109 Journal of Political Economy 203. But the assumptions animating the KPT have been powerfully challenged in part by pointing out that under most circumstances, members of racial groups diffused across the public lack sufficient evidence of police practice to respond dynamically to changes in policing in ways that produce the equilibria that KPT implies. Engel RS and Tillyer R, 'Searching for Equilibrium: The Tenuous Nature of the Outcome Test' (2008) 25 Justice Quarterly 54. That is, the KPT model assumes that the public is fully informed of police behavior and responds rationally by varying up or down their level of criminality in response to that behavior. I am skeptical that behavioural elasticity of the sort the KPT equilibrium assumes is likely to hold in the counterterrorism context. Instead, the relative offending rates of 'Muslim seeming' and 'non-Muslim seeming' groups is a function of variables exogenous to dynamic reactions to policing practices, such as experiences of economic disenfranchisement, changes in the levels of external propaganda, and personal disappointments and grievances. I therefore do not think the empirical question of comparative elasticities is as important as Harcourt suggests it is in the national security context. In other word, I have expressed skepticism about its relevance in the ordinary policing context. Huq A, 'The Consequences of Disparate Policing' (forthcoming 2017) 101 Minnesota Law Review --.
} 


\section{New Paths for Critical Inquiry}

Viewed in the round, the concept of Islam in counterterrorism today performs a number of functions unrelated to the efficient allocation of security resources. Accounting for this broader array of uses of Islam in the service of counterterrorism should elicit new inquiries into the aggregate impact and political economy of counterterrorism and related fields. I offer, in concluding, a sketch of some of these lines of critique.

First, an analysis of security policy is useful situated in the larger context of public debates on Muslim migration and public symbols of Islam. These debates suggest that officials and members of the public juxtapose the moral legitimacy of the liberal state with the perceived normative bankruptcy of Islam. ${ }^{59}$ Muslims are simultaneously figured as incapable of respecting basic norms of dress and civility, and also of discarding basic rules of moral conduct. The claim that Islam "has no place" in Europe is thus based on parallel concerns about culture and security. It seems likely that those parallel concerns are mutually reinforcing. Both imply that Muslims are incapable of coexisting peacefully with non-Muslim neighbors. In this fashion, debates about national culture and national security may be mutually constitutive, and mutually reinforcing.

One implication of this analysis may be that debates about highly visible symbols of Islam, such as the veil or the minaret, are counterproductive for advocates of nondiscrimination and Muslim human rights. These debates condense the relationship of Muslim minorities to nonMuslim majorities into singular points of highly charged contestation that are resistant to compromise. Such debates obscure the fact that Muslim minority communities and their neighbors in fact engage routinely in negotiation and reach compromise over many issues. Indeed, such negotiated coexistence is the dominant local experience in the Netherlands and the United Kingdom. ${ }^{60}$ The tendency to highlight symbolic conflicts, while ignoring local and pragmatic intercultural relations, renders the putative tensions between Islam and liberalism as sharper, and less amenable to compromise, than they really are. As a result, they may push participants toward more extreme solutions in the security domain and elsewhere.

Second, my analysis of Islam's varied role in security policy suggests a need to account for distributive effects, and in particular how the costs of security are apportioned between marginal and mainstream groups across society. The profiling, reformist efforts, and prohibitory policies described above all have the likely effect of exacerbating existing forms of economic and social exclusion. The result may, paradoxically, be less security rather than more.

France provides a useful example of this dynamic. Recent research by Claire Adida, David Laitin, and Marie-Anne Valfort uses sophisticated causal inference methods to isolate the effect of Islamic or Muslim identities on the labor market and economic behavior of French nationals more generally. They provide robust evidence of substantial discrimination on the basis of perceived religious identity in the context of face-to-face interactions and arms-length economic transactions. ${ }^{61}$ President Hollande's recent deployment of emergency powers has likely exacerbated French Muslims' economic marginalization and social subordination by validating the beliefs that animate such discrimination. The implicit expressive effect of profiling under Section 44 and the Prevent program likely have the same consequence. Hence, the securitization

\footnotetext{
${ }^{59}$ This theme is developed in Massad JA, Islam in Liberalism (Chicago, University Of Chicago Press 2016).

${ }^{60}$ For recent accounts of successful local practice, see Korteweg AC and Triadafilopoulos T, 'Is Multiculturalism Dead? Groups, Governments and the "real Work of Integration"' (2015) 38 Ethnic and Racial Studies 663; Heath A and Demireva N, 'Has Multiculturalism Failed in Britain?' (2014) 37 Ethnic \& Racial Studies 161

${ }^{61}$ Adida CL, Laitin DD and Valfort M-A, Why Muslim Integration Fails in Christian-Heritage Societies (Cambridge, Harvard University Press 2016)
} 
of Islam not only provides a substitute for discussion of the limits of practiced liberalism, but also deepens the exclusionary elements of the liberal economic order.

Economic and social marginalization further erodes security. Empirical studies in the United States and Britain show that policing perceived as biased against Muslims undermines both Muslims' and non-Muslims' willingness to cooperate with police. ${ }^{62}$ At the same time, a growing body of robust evidence suggests that countries experiencing minority group economic discrimination are significantly more likely to experience domestic terrorism attacks. ${ }^{63}$ If there is a strong correlation between minority economic exclusion and domestic terrorism, security policies that exacerbate such exclusion, or retrench negative stereotypes of Muslims, will have perverse and adverse effects on terrorism risk. Because politicians can profit from the cultivation of anti-Muslim sentiments, though, these negative spillovers are unlikely to be accounted for in policy-making.

Finally, the question of Islam and Muslims in the counterterrorism context is usefully viewed not merely as a matter of individual rights, but also as an issue of distributive justice. In the past decade and a half, the costs of the security state's expansion have not fallen evenly across social groups. The increasingly flexible role of Islam across a number of specific policy areas, the costs of such policies fall in predictably asymmetrical, and highly regressive, patterns. To be sure, programs such as Prevent have had the inadvertent and temporary effect of channeling state funds to Muslim-identified groups. By and large, though, the costs of security are borne by Muslims, in the forms of concentrated stigma, economic exclusion, fear of private violence, and barriers to familial reunification. In France and other European countries, Muslims tend toward the more impoverished end of the income and wealth scale.

Security against terrorism is a public good that all enjoy. It is unjust for the costs of its production to be concentrated on one minority group. This would be so even if there were good efficiency reasons for that concentration. But there are not. Profiling and selective coercion are measures of dubious worth. Extirpation is based on false and pernicious stereotyping of the gap between Islam and 'Western' culture. Reformist efforts raise the important question of how much the state can legitimately shape confessional practice. These questions must be considered in light of the fact that Muslim citizens have, if anything, a special contribution to make in terms of the kinds of arguments and social mobilization they can (and do) bring to bear against IS's and al Qaeda's propaganda. ${ }^{64}$ How this contribution can be recognized and cultivated, while ensuring that the burdens of security are equitably distributed - this in my view is the central challenge of contemporary counterterrorism, a challenge that sounds as much in distributive justice terms as it does in the values captured by individual rights.

\footnotetext{
${ }^{62}$ For a summary and extension of these studies, see Huq AZ, Tyler TR and Schulhofer SJ, 'Mechanisms for Eliciting Cooperation in Counterterrorism Policing: Evidence from the United Kingdom’ (2011) 8 Journal of Empirical Legal Studies 728.

${ }^{63}$ Piazza JA, 'Poverty, Minority Economic Discrimination, and Domestic Terrorism' (2011) 48 Journal of Peace Research 339, 347-49; Piazza JA, 'Types of Minority Discrimination and Terrorism' (2012) 29 Conflict Management and Peace Science 521, 536; Ghatak S and Gold A, 'Development, Discrimination, and Domestic Terrorism: Looking beyond a Linear Relationship' (2015) Conflict Management and Peace Science 1.

${ }^{64} \mathrm{I}$ have developed this argument at length in Huq (2013).
} 


\section{Conclusion}

The dynamics mapped in this chapter will likely deepen in the near term as right-ofcenter populists in Europe and the United States exercise a greater measure of political influence. To date, judicial review and administrative mechanisms alike have failed to provide much traction against the rights-related and distributive inequities of security policy. Nevertheless, domestic Muslim civil-society organizations are increasingly vocal in their resistance to the myriad uses of Islam for security ends. ${ }^{65}$ This chapter has described the challenge they face. Alas, it is a challenge that will not be surmounted quickly, or without great cost on the part of European and American Muslims.

\section{Bibliography}

Adida CL, Laitin DD and Valfort M-A, Why Muslim Integration Fails in Christian-Heritage Societies (1st edn, Harvard University Press 2016)

Akkerman T, 'Immigration Policy and Electoral Competition in Western Europe: A Fine-Grained Analysis of Party Positions over the Past Two Decades' (2015) 21 Party Politics 54

Alam Y and Husband C, 'Islamophobia, Community Cohesion and Counter-Terrorism Policies in Britain' (2013) 47 Patterns of Prejudice 235

Alexander JC, 'Struggling over the Mode of Incorporation: Backlash against Multiculturalism in Europe' (2013) 36 Ethnic and Racial Studies 531

Al-Marayati L, 'American Muslim Charities: Easy Targets in the War on Terror' (2004) 25 Pace Law Review 321

Amnesty International, Upturned Lives: The Disproportionate Impact of France's State of Emergency (4 February 2016) < https://www.amnesty.org/en/documents/eur21/3364/2016/en/ accessed 14 September 2016

Apuzzo M and Baker A, 'New York to Appoint Civilian to Monitor Police's Counterterrorism Activity' The New York Times (7 January 2016)

<http://www.nytimes.com/2016/01/08/nyregion/new-york-to-appoint-monitor-to-review-policescounterterrorism-activity.html> accessed 14 September 2016

Apuzzo M and Goldman A, Enemies Within: Inside the NYPD's Secret Spying Unit and Bin Laden's Final Plot Against America (Touchstone 2013)

Bakker E, 'EU Counter-Radicalization Policies: A Comprehensive and Consistent Approach?' (2015) 30 Intelligence and National Security 281

Bakker E and Singleton M, 'Foreign Fighters in the Syria and Iraq Conflict: Statistics and Characteristics of a Rapidly Growing Phenomenon' in Andrea de Guttry, Francesca Capone and Christophe Paulussen (eds), Foreign Fighters under International Law and Beyond (TMC Asser Press 2016) <http://link.springer.com/chapter/10.1007/978-94-6265-099-2_2> accessed 13 September 2016

Bigo D, 'Security and Immigration: Toward a Critique of the Governmentality of Unease' (2002) 27 Alternatives: Global, Local, Political 63

Bilefsky D, 'Denmark's Tougher Citizenship Test Stumps Even Its Natives' The New York Times (7 July 2016) <http://www.nytimes.com/2016/07/08/world/europe/denmark-citizenshiptest.html > accessed 15 September 2016

Briggs R, 'Community Engagement for Counterterrorism: Lessons from the United Kingdom' (2010) 86 International Affairs 971

Cockburn P, The Rise of Islamic State: ISIS and the New Sunni Revolution (Verso Books 2015)

${ }^{65}$ Edmonds (2011). 
Cook D, 'Apostasy from Islam: A Historical Perspective' (2006) 31 Jerusalem Studies in Arabic and Islam 248

Coppock V and McGovern M, “Dangerous Minds"? Deconstructing Counter-Terrorism

Discourse, Radicalisation and the "Psychological Vulnerability" of Muslim Children and Young People in Britain' (2014) 28 Children \& Society 242

Dempsey J, 'Civic Test in Germany Draws Fire' The New York Times (14 February 2006)

<http://www.nytimes.com/2006/02/14/world/europe/civic-test-in-germany-draws-fire.html> accessed 15 September 2016

Edmunds J, 'The "new" Barbarians: Governmentality, Securitization and Islam in Western

Europe' (2011) 6 Contemporary Islam 67

Engel RS and Tillyer R, 'Searching for Equilibrium: The Tenuous Nature of the Outcome Test' (2008) 25 Justice Quarterly 54

Farwell JP, 'The Media Strategy of ISIS' (2014) 56 Survival 49

Foley F, 'Reforming Counterterrorism: Institutions and Organizational Routines in Britain and France' (2009) 18 Security Studies 435

Garland D, "'Governmentality" and the Problem of Crime: Foucault, Criminology, Sociology' (1997) 1 Theoretical Criminology 173

Gayle D, 'Prevent Strategy "Could End up Promoting Extremism"' The Guardian (21 April

2016) <http://www .theguardian.com/politics/2016/apr/21/government-prevent-strategy-

promoting-extremism-maina-kiai> accessed 15 September 2016

Gerges FA, 'The Far Enemy: Why Jihad Went Global' (Foreign Affairs, 28 January 2009)

$<$ https://www .foreignaffairs.com/reviews/capsule-review/2005-11-01/far-enemy-why-jihad-wentglobal> accessed 13 September 2016

Ghatak S and Gold A, 'Development, Discrimination, and Domestic Terrorism: Looking beyond a Linear Relationship' [2015] Conflict Management and Peace Science 738894215608511

Göle N, 'The Voluntary Adoption of Islamic Stigma Symbols' (2003) 70 Social Research 809

- - 'The Public Visibility of Islam and European Politics of Resentment: The Minarets-

Mosques Debate' (2011) 37 Philosophy \& Social Criticism 383

Goodman SW, 'Controlling Immigration through Language and Country Knowledge

Requirements' (2011) 34 West European Politics 235

Goold BJ and Lazarus L, Security and Human Rights (Bloomsbury Publishing 2007)

Gregory S, 'France and the War on Terrorism' (2003) 15 Terrorism and Political Violence 124

Hafez F, 'Shifting Borders: Islamophobia as Common Ground for Building Pan-European Right-

Wing Unity' (2014) 48 Patterns of Prejudice 479

Hallsworth S, 'Racial Targeting and Social Control: Looking behind the Police' (2006) 14

Critical Criminology 293

Heath A and Demireva N, 'Has Multiculturalism Failed in Britain?' (2014) 37 Ethnic \& Racial

Studies 161

Heath-Kelly C, "Counter-Terrorism and the Counterfactual: Producing the "Radicalisation"

Discourse and the UK PREVENT Strategy' (2013) 15 The British Journal of Politics and

International Relations 394

Hellmuth D, 'Countering Jihadi Terrorists and Radicals the French Way' (2015) 38 Studies in

Conflict and Terrorism 979

Hupe P and Hill M, 'Street-Level Bureaucracy and Public Accountability' (2007) 85 Public

Administration 279

Huq AZ, 'Modeling Terrorist Radicalization' (2010) 2 Duke Forum for Law and Social Change 39

- - , 'Private Religious Discrimination, National Security, and the First Amendment' (2011) 5

Harvard Law \& Policy Review 347

- - , 'The Social Production of National Security' (2012) 98 Cornell Law Review 637 
- - 'The Consequences of Disparate Policing' (forthcoming 2017) 101 Minnesota Law Review $--$

Huq AZ, Tyler TR and Schulhofer SJ, 'Mechanisms for Eliciting Cooperation in

Counterterrorism Policing: Evidence from the United Kingdom' (2011) 8 Journal of Empirical

Legal Studies 728

Ingram HJ, 'The Strategic Logic of Islamic State Information Operations' (2015) 69 Australian

Journal of International Affairs 729

'Islam Is Europe's "new Fascism," and Other Things European Politicians Say about Muslims' (Washington Post) <https://www.washingtonpost.com/news/worldviews/wp/2016/06/07/tenthings-outspoken-european-politicians-are-saying-about-islam/> accessed 15 September 2016 Ivarsflaten E, 'What Unites Right-Wing Populists in Western Europe? Re-Examining Grievance Mobilization Models in Seven Successful Cases' (2008) 41 Comparative Political Studies 3 Joppke C, 'Through the European Looking Glass: Citizenship Tests in the USA, Australia, and Canada' (2013) 17 Citizenship Studies 1

- - , 'Terror and the Loss of Citizenship' (2016) 20 Citizenship Studies 728

Kennedy H, The Caliphate (Pelican 2016)

Knowles J, Persico N and Todd P, 'Racial Bias in Motor Vehicle Searches: Theory and Evidence' (2001) 109 Journal of Political Economy 203

Korteweg AC and Triadafilopoulos T, 'Is Multiculturalism Dead? Groups, Governments and the "real Work of Integration"' (2015) 38 Ethnic and Racial Studies 663

Kurzman C, The Missing Martyrs: Why There Are So Few Muslim Terrorists (1 edition, Oxford University Press 2011)

Leeuw M de and Wichelen S van, 'Civilizing Migrants: Integration, Culture and Citizenship' (2012) 15 European Journal of Cultural Studies 195

Lindekilde L, 'Value for Money? Problems of Impact Assessment of Counter-Radicalization Policies on End Target Groups: The Case of Denmark' (2012) 18 European Journal on Criminal Policy and Research 385

Lindekilde L, Bertelsen P and Stohl M, 'Who Goes, Why, and With What Effects: The Problem of Foreign Fighters from Europe' (2016) 27 Small Wars \& Insurgencies 858

Massad JA, Islam in Liberalism (Reprint edition, University Of Chicago Press 2016)

Moeckli D, Human Rights and Non-Discrimination in the 'War on Terror' (1 edition, Oxford University Press 2008)

Mythen G, Walklate S and Khan F, 'II'm a Muslim, but I'm Not a Terrorist': Victimization, Risky Identities and the Performance of Safety' (2009) 49 British Journal of Criminology 736 Neumann PR, 'The Trouble with Radicalization' (2013) 89 International Affairs 873 O'Toole T and others, 'Governing through Prevent? Regulation and Contested Practice in StateMuslim Engagement' (2016) 50 Sociology 160

Office of the Inspector General-NYPD, 'An Investigation of NYPD's Compliance with Rules Governing Investigations of Political Activity' (23 August 2016) <

http://www1.nyc.gov/site/oignypd/reports/reports.page> accessed 22 September 2016.

Pantazis C and Pemberton S, "From the "Old" to the "New" Suspect Community Examining the Impacts of Recent UK Counter-Terrorist Legislation' (2009) 49 British Journal of Criminology 646

Piazza JA, 'Poverty, Minority Economic Discrimination, and Domestic Terrorism' (2011) 48 Journal of Peace Research 339

- - , 'Types of Minority Discrimination and Terrorism' (2012) 29 Conflict Management and Peace Science 521

Ragazzi F, 'Toward "Policed Multiculturalism"? Counter-radicalization in France, the Netherlands and the United Kingdom' Centre d'Études et de Recherches Internationales (December 2014) <

http://www.sciencespo.fr/ceri/sites/sciencespo.fr.ceri/files/Etude_206_anglais.pdf> 
Rubin AJ, 'Muslims in France Say Emergency Powers Go Too Far' The New York Times (17 February 2016) <http://www.nytimes.com/2016/02/18/world/europe/frances-emergency-powersspur-charges-of-overreach-from-muslims.html> accessed 14 September 2016

Rydgren J, 'Immigration Skeptics, Xenophobes or Racists? Radical Right-Wing Voting in Six West European Countries' (2008) 47 European Journal of Political Research 737

Scheppele KL, 'Other People's Patriot Acts: Europe's Response to September 11' (2004) 50 Loyola Law Review 89

'The Islamic Veil across Europe' BBC News (1 July 2014) <http://www.bbc.com/news/worldeurope-13038095> accessed 14 September 2016

Theoharis J, "I Feel Like a Despised Insect": Coming of Age Under Surveillance in New York' (The Intercept) <https://theintercept.com/2016/02/18/coming-of-age-under-surveillance-in-newyork/> accessed 14 September 2016

Thomas P, Responding to the Threat of Violent Extremism: Failing to Prevent (A\& C Black 2012)

Vertigans S, 'British Muslims and the UK Government's "war on Terror" within: Evidence of a Clash of Civilizations or Emergent de-Civilizing Processes?' (2010) 61 The British Journal of Sociology 26

Weimann G, 'The Emerging Role of Social Media in the Recruitment of Foreign Fighters' in Andrea de Guttry, Francesca Capone and Christophe Paulussen (eds), Foreign Fighters under International Law and Beyond (TMC Asser Press 2016)

$<$ http://link.springer.com/chapter/10.1007/978-94-6265-099-2_6> accessed 13 September 2016 Yilmaz F, 'Right-Wing Hegemony and Immigration: How the Populist Far-Right Achieved Hegemony through the Immigration Debate in Europe' (2012) 60 Current Sociology 368 Zelin AY, 'Picture Or It Didn't Happen: A Snapshot of the Islamic State's Official Media Output' (2015) 9 Perspectives on Terrorism

<http://www.terrorismanalysts.com/pt/index.php/pot/article/view/445> accessed 13 September 2016

Zucchino D, “'I've Become a Racist': Migrant Wave Unleashes Danish Tensions Over Identity' The New York Times (5 September 2016)

<http://www.nytimes.com/2016/09/06/world/europe/denmark-migrants-refugees-racism.html> accessed 13 September 2016 